Paedagogia Christiana

2/28 (201 I) - ISSN 1505-6872

Stanisław Jaromi*

Kraków

\title{
Ruchy i stowarzyszenia w Kościele w służbie ekologii
}

W czasie powstawania Kościoła i jeszcze przez wiele kolejnych lat nie zajmowano się problematyką ekologiczną. Biblia, jako księga wiary, przedstawia historię spotkania Boga i człowieka. Historia ta rozgrywa się w konkretnej przestrzeni, w środowisku życia ludzkiego. Choć więc nie zawiera ona jakiejś etyki odnoszącej się do stworzeń, można w niej znaleźć kilka modelowych relacji człowieka do przyrody. Trudno w tym miejscu dokładnie śledzić, jak biblijne modele wyrażające relację przyroda-człowiek-Bóg kształtowały kolejne pokolenia chrześcijan. Tematy te zostały podjęte $\mathrm{w}$ innych tekstach tego tomu. W niniejszym artykule chcę jedynie krótko zaprezentować podstawy teoretyczne zaangażowania katolików w aktywność proekologiczną oraz wybrane przykłady takich działań podejmowane w polskim Kościele.

\section{Chrześcijańska wizja stworzenia bazą zaangażowania proekologicznego}

Gdy próbujemy budować integralną, chrześcijańską wizję stworzenia, nie sposób pominąć kontekstu współczesności: naszą obecną wiedzę na te-

* Dr Stanisław Jaromi OFMConv, przewodniczący Ruchu Ekologicznego św. Franciszka z Asyżu (REFA); wykładowca na Uniwersytecie Papieskim Jana Pawła II w Krakowie,w Akademii Ochrony Przyrody Polskiej Akademii Nauk i w Wyższym Seminarium Duchownym Franciszkanów w Krakowie. 
mat przyrody, kryzysu ekologicznego czy refleksję nad zjawiskami społecznymi, kulturowymi, gospodarczymi. Zauważamy na przykład, że tam, gdzie ludzie są uciskani, tam na ogół przyrodę eksploatuje się bezmyślnie, a wojna jest jedną z największych katastrof ekologicznych. I odwrotnie: niszczenie przyrody niesie za sobą niszczenie wspólnoty ludzkiej. Dobrze ową sytuację ilustruje znana metafora, gdy o efektywnej pomocy bliźnim w potrzebie mówimy: „trzeba dać wędkę a nie gotową rybę”. Kościół stara się dawać i jedno, i drugie. Gotową rybą jest działalność typu CARITAS: zasiłki ubogim, żywność głodującym, leki i opieka medyczna chorym, wspólnoty i grupy wsparcia dla samotnych, ośrodki pomocy w kłopotach rodzinno-społecznych itd. Wędką jest aktywność typu IUSTITA ET PAX, zadająca pytania o źródła niesprawiedliwości i niepokojów w świecie, podejmująca kwestie pojednania społecznego i troski o dobro wspólne. Ale wiadomo, że ani wędka, ani to wszystko na nic się nie przyda, gdy jezioro wyschło lub jest zatrute. Taką sytuację Kościołowi i całemu światu ukazał kryzys ekologiczny.

Niezwykle ciekawie z tym wyzwaniem zmaga się papież Benedykt XVI. W jego wywiadzie z Peterem Seewaldem pod tytułem Świattość świata znajdujemy mocne wątki ekologiczne. Jest cytowany sekretarz generalny Narodów Zjednoczonych, Ban Ki-moon, który określając stan planety Ziemi przed Zgromadzeniem ONZ w listopadzie 2007 roku uznał, że jest ona ,ekstremalnie zagrożona", że ludzkości pozostaje już niewiele dziesięcioleci do osiągnięcia point of no return (punktu, z którego nie ma odwrotu). Jest mowa o kryzysie ekologicznym i klimatycznym, o tym, że bieguny topnieją, dziury ozonowe nie zmniejszają się, o wycieku ropy w Zatoce Meksykańskiej, pożarach wielkich obszarów, nieporównywalnych z niczym powodziach, niespodziewanych falach upałów i okresach długotrwałej suszy. Diagnoza Seewalda jest mocna: „«Bóg widział, że wszystko, co stworzył, było bardzo dobre» - czytamy w Księdze Rodzaju. Przerażające, co od tamtego czasu stało się z tą piękną planetą"2.

Jak odpowiedzieć na ostrzeżenia o tym, że stan planety Ziemi jest ekstremalnie zagrożony, że ludzkości już niewiele zostało do osiągnięcia punktu, z którego nie ma odwrotu, że ludzkość popełniła karygodne błędy w swym rozwoju? „To rzeczywiście jest wielki problem” - mówi Papież i wzywa zarówno do odpowiedzialnej polityki, jak i właściwych osobistych decyzji. Widzi również w tym „wyzwanie dla Kościoła”.

Pelny tytuł książki brzmi: Świattość świata. Papież, Kościół i znaki czasu, i ekologiczne znaki czasu są tam potraktowane bardzo poważnie. Dla wielu było zaskoczeniem, że wybitny teolog i przywódca Kościoła katolic-

2 Benedykt XVI w rozmowie Peterem Seewaldem, Świattość świata. Papież, Kościót i znaki czasu, Kraków 2011, s. 53. 
kiego mówi o ekologii i zmianach klimatycznych. Zaskoczeniem tak dużym, iż nieliczne polskie komentarze pominęły takie wątki. Tak jak je pomijały w analizach encykliki Caritas in veritate czy orędziu na światowy dzień pokoju z 1 stycznia 2010 roku pod tytułem: Jeśli chcesz dbać o pokój, otocz troska stworzenie. Czy jak je pomijały w licznych tekstach Jana Pawła II, w jego encyklikach, orędziach, katechezach i homiliach. Dla niego teksty „o stworzeniu” - zwłaszcza dwa pierwsze rozdziały Księgi Rodzaju - były przedmiotem szczególnie żywego zainteresowania. Już w pierwszych tygodniach pontyfikatu, w przemówieniach do wiernych w Adwencie 1978 roku, przeprowadził egzegezę kart Księgi Rodzaju mówiących o dziele stworzenia. Od 8 stycznia do 20 sierpnia 1986 roku podczas środowych audiencji ogólnych wygłosił cykl katechez na temat wiary w Boga Stworzyciela. Twierdząc, iż „świadomość stworzenia w optyce Vaticanum II lączy się ściśle ze świadomością odkupienia"3 społecznej.

Duże zainteresowanie Ojca Świętego Jana Pawła II teologią stworzenia wynikało z jego przekonania o konieczności częstszego mówienia o Bogu jako Stworzycielu. Być może wynikało to między innymi z chęci nadrobienia powstałych w tej dziedzinie zaległości, bowiem - jak zauważa o. prof. Zdzisław Kijas - długo brakowało ,poważnych studiów w tym zakresie, będących w stanie rozjaśnić czy wyjaśnić w sposób właściwy relacje zachodzące między człowiekiem i światem, Biblią i wiarą Kościoła a nauką" ${ }^{4}$. Ich brak sprawiał, że chrześcijański przekaz prawdy o stworzeniu cierpiał na wiarygodności. Kryzys ekologiczny był okazją do głębszego zainteresowania się również tą problematyką, tym bardziej, że świadomość owych właściwych relacji może - zdaniem papieża Jana Pawła II - pomóc tym, którzy starają się przeciwdziałać nieodpowiedzialnemu wykorzystaniu przyrody i niszczeniu ziemi. Dla innych prawda o stworzeniu może nieść radość z piękna i wspaniałości świata, będącą udziałem w radości samego Stworzyciela. Wniosek taki Papież uzasadnia wyrażonym w Biblii zachwytem Boga nad światem przed pierworodnym upadkiem człowieka: „A Bóg widział, że wszystko, co uczynił, było bardzo dobre" (Rdz 1,31) . s. 58.

${ }^{3}$ K. Wojtyła, U podstaw odnowy. Studium o realizacji Vaticanum II, Kraków 1988,

${ }^{4}$ Z. Kijas, Początki świata i człowieka, Kraków 2004, s. 8.

5 Jan Paweł II, Wierzę w Boga Ojca Stworzyciela, Città del Vaticano 1987. Książka jest zapisem katechez papieskich na temat wiary w Boga Stworzyciela. 


\section{Ekologia w refleksji Kościoła}

Katolicka refleksja nad współczesną kulturą, przyrodą, naturalnym środowiskiem człowieka rozwijana jest od ponad 40 lat. Wyrasta z bogatej tradycji chrześcijańskiej refleksji nad problemami współczesności i jest rozwijana konsekwentnie zarówno w ściśle naukowych przesłaniach do Papieskiej Akademii Nauk, jak również w popularnych homiliach i kazaniach, wyrażających istotę chrześcijańskiej koncepcji środowiska naturalnego. Choć ma ona charakter całościowy i duże walory teoriopoznawcze, zaś jej autorzy są dobrze znani, uderza jej praktyczna nieobecność we współczesnych pracach z zakresu filozofii czy polityki ekologicznej. Być może jest tak dlatego, iż jej bazą jest chrześcijańska Ewangelia życia. Zapewne jest ona dobrze znana, przypomnę więc jedynie jej najważniejsze, jak się wydaje, tezy:

- życie jest darem;

- życie ludzkie jest święte od poczęcia aż do kresu;

- rodzina jest szczególnym sanktuarium życia;

- „głównym bogactwem człowieka jest wraz z ziemią sam człowiek” $(\mathrm{CA} 32)^{6}$;

- prawidłowa równowaga ekologiczna jest niemożliwa do osiągnięcia, zanim nie zostanie rozwiązana sprawa strukturalnych form ubóstwa istniejącego na świecie (por. CA 7);

- ochrona życia na ziemi jest głównym celem wszystkich programów środowiskowych;

- wojna jest największą katastrofą społeczną i ekologiczną;

- biosfera jest powiązana z socjosferą, a kultura współkonstytuuje przyrodę (a owe relacje są zarówno ujemne, jak i dodatnie);

- alienacja człowieka wobec przyrody jest w konsekwencji działaniem przeciw kulturze życia, ale też wszelkie próby ochrony przyrody muszą obejmować kontekst społeczny;

- nowa solidarność ekologiczna powinna obejmować zarówno relacje wewnątrz społeczności ludzkiej, troskę o przyszłe pokolenia, jak również stosunek do przyrody i środowiska naturalnego ${ }^{7}$.

Wydaje się, iż odnosząc się bezpośrednio do źródeł, doktrynę ekologiczną Kościoła można przedstawić poprzez kilka cytatów z nauczania Jana Pawła II. Szczególnie często eksponowany jest cytat z pierwszej „,programo-

6 Tenże, Encyklika Centesimus annus, w: Encykliki Ojca Świętego Jana Pawła II, t. II, Kraków 1996 - w tekście CA z odnośnym numerem.

${ }^{7}$ Szeroko omawiam te zagadnienia w: S. Jaromi, Ecologia humana - chrześcijańska odpowiedź na kryzys ekologiczny, Kraków 2004. 
wej” encykliki papieża Jana Pawła II Redemptor hominis: „Człowiek dzisiejszy zdaje się być stale zagrożony przez to, co jest jego własnym wytworem [...] Coraz bardziej bytuje w lęku [...] Nie dostrzega innych znaczeń swego naturalnego środowiska, jak tylko te, które służą celom doraźnego użycia i zużycia. Tymczasem Stwórca chciał, aby człowiek obcował z przyrodą jako jej rozumny i szlachetny «pan» i «stróż», a nie jako bezwzględny «eksploatator»" $(\mathrm{RH} 15)^{8}$.

Ta rozwijana w kolejnych wystąpieniach piękna myśl o relacji ludzi do przyrody ukazuje człowieka jako «pasterza przyrody»" ${ }^{9}$, «dobrego gospodarza», «szafarza» rozdzielającego dobra z Bożym błogosławieństwem. Jest to bliskie rozwijanej przez ekoteologów idei stewardship, która proponuje, aby chrześcijańskie cnoty pokory, współczucia i miłości do słabych i odrzucanych objęły również całe stworzenie według zalecenia Chrystusa: „Cokolwiek uczyniliście jednemu z tych najmniejszych, mieście uczynili” $(\mathrm{Mt} 25,40)^{10}$.

W najobszerniejszym dokumencie Jana Pawła II w kwestii ekologicznej, w orędziu na światowy dzień pokoju 1 stycznia 1990 roku pod tytułem Pokój z Bogiem Stwórca - pokój z calym stworzeniem, czytamy: „Najgłębszą i najpoważniejszą implikacją moralną kwestii ekologicznej jest brak szacunku dla życia, który charakteryzuje wiele zachowań sprzecznych z zasadami ochrony środowiska" 11 .

Okazuje się, iż niemal wszystkie współczesne problemy społeczne, gospodarcze, polityczne, cywilizacyjne, ekologiczne, a nawet techniczne są ostatecznie sprowadzone do zagadnienia moralnego odrodzenia i przemiany człowieka, jako warunków ich rozwiązania. Wynika stąd wprost ważny postulat formacyjny dla ruchów i stowarzyszeń kościelnych.

W Polsce szczególną inspirację dały słowa Ojca Świętego Jana Pawła II w Zamościu w 1999 roku. Zaskoczył On wtedy wielu słuchaczy, poświęcając swoje przemówienie głównie kwestii ekologicznej:

8 Jan Paweł II, Encyklika Redemptor hominis, w: Encykliki Ojca Świętego Jana Pawła II, t. I, Kraków 1996 - w tekście RH z odnośnym numerem.

${ }^{9}$ Biblijna metafora pasterza i owiec podkreśla charakterystyczne własności dobrego pasterza: jego zadaniem jest prowadzić owce na miejsca bezpieczne, obfite w wodę i pokarm, chronić je przez niebezpieczeństwem nawet z narażeniem własnego życia, dbać zwłaszcza o te, które się zagubiły. Pasterz, inaczej niż hodowca, nie ingeruje w życie owiec (przyrody).

${ }^{10}$ Por. C. Deane-Drummond, A Handbook in Theology and Ecology, London 1996; L. Osborn, Guardians of Creation. Nature in theology and the Christian life, Leicester 1993.

${ }^{11}$ Jan Paweł II, Orędzie na XXIII Światowy Dzień Pokoju 1.01.1990 r., w: Orędzia Ojca Świętego Jana Pawła II, t. 1, Kraków 1998, s. 105-113. 
Kiedy wędruję po polskiej ziemi, od Bałtyku, przez Wielkopolskę, Mazowsze, Warmię i Mazury, kolejne ziemie wschodnie od Białostockiej aż do Zamojskiej, i kontempluję piękno tej ojczystej ziemi, uprzytamniam sobie ten szczególny wymiar zbawczej misji Syna Bożego. Tu z wyjątkową mocą zdaje się przemawiać błękit nieba, zieleń lasów i pól, srebro jezior i rzek. Tu śpiew ptaków brzmi szczególnie znajomo, po polsku. A wszystko to świadczy o miłości Stwórcy, o ożywczej mocy Jego Ducha i o odkupieniu, którego Syn dokonał dla człowieka i dla świata. Piękno tej ziemi skłania mnie do wołania o jej zachowanie dla przyszłych pokoleń [...] Wszyscy ludzie dobrej woli winni współdziałać w tym wielkim dziele. Każdy z uczniów Chrystusa niech weryfikuje styl swego życia, aby słuszne dążenie do pomyślności nie zagłuszyło głosu sumienia, które waży to, co słuszne i prawdziwie dobre ${ }^{12}$.

Widzimy, że papież Jan Paweł II nie unikał tematów trudnych, choć nie podawał gotowych recept na rozwiązanie problemów współczesnego świata. Znamienną cechę intelektualnego przesłania zawartego w jego nauczaniu stanowi wizja wielkiej integracji, prowadząca do przezwyciężania podziałów oraz budowania fundamentów nadziei dla konkretnych ludzi i całej cywilizacji. W Zamościu papieskie przesłanie zostało skierowane wprost do Polaków. Czy zechcemy je przyjąć? Czy spróbujemy je wdrażać w nasze życie? Czy nasi decydenci i politycy, odpowiedzialni za realizację programów rozwoju kraju, chcą wsłuchać się w głos Kościoła i Papieża? Czy zatroskanie Jana Pawła II o polską przyrodę i ochronę życia pobudzi i nas do większej odpowiedzialności za świat, w którym żyjemy?

\section{Chrześcijańska ekologia we współczesnym świecie}

Chrześcijańska Ewangelia życia wraz z koncepcją ekologii ludzkiej jest ważną próbą całościowej odpowiedzi na złożone wyzwania współczesności, zwłaszcza na zjawisko kryzysu ekologicznego. Prezentuje też nową, integralną wizję stworzonego świata i koncepcję rozwoju społecznego, który jest zharmonizowany z przyrodą. Stanowi też mocny głos Kościoła katolickiego w dyskusjach nad kształtem świata, w którym żyjemy razem z wszystkimi zwierzętami i roślinami. Jednakże zastanawiający jest pewien paradoks: jak to jest, że ów dziedzic Bożego stworzenia, który aktywnie uczestniczy w odnowie oblicza ziemi, umie też to oblicze zniekształcać i niszczyć, jak

12 Tenże, Homilia w Zamościu 12.06.1999 r., „L’Osservatore Romano” 8/215 (1999), s. 71 . 
o tym świadczą wojny i katastrofy ekologiczne, które szkodzą człowiekowi i niszczą naturalne środowisko życia na globie ziemskim? ${ }^{13}$

Zainteresowanie środowiskiem naturalnym wybuchło w drugiej połowie lat sześćdziesiątych XX wieku. Okazało się bowiem, że jego stan zaczął budzić obawy o przyszłość ludzkości. I chociaż często nie dopuszczamy do siebie takiej myśli, prawdą jest, że nie możemy żyć bez odpowiedniego dla nas środowiska. W XIX wieku w ramach biologii powstała specjalna nauka zajmująca się wzajemnymi stosunkami między organizmami a ich środowiskiem. Ernst Haeckel nazwał ją w 1866 roku ekologią. Dziś to jedno z bardziej modnych słów, używane na wszystkie możliwe sposoby.

Dla chrześcijanina ochrona środowiska naturalnego wypływa z przykazania miłości bliźniego i siebie. Odpowiedzialność za przyrodę jest wyrazem miłości Boga i Jego dzieł. Według Ojca Świętego Jana Pawła II, najlepiej nasz stosunek do innych stworzeń określają słowa „stróż”, „gospodarz” (por. RH 15). Świat został nam powierzony (por. Rdz 1, 27-31. 2, 15) i kiedyś będziemy składać raport ze swej działalności. „Cóż to słyszę o tobie? Zdaj sprawę z twego zarządu..." - być może zapyta Bóg, jak w owej ewangelijnej przypowieści (por. Łk 16, 1 n).

W Polsce w latach osiemdziesiątych po ujawnieniu ogromu zniszczeń środowiska naturalnego na skutek rabunkowej i nieprzestrzegającej żadnych norm działalności gospodarczej w PRL-u, środowiska katolickie mocno zaangażowały się w różnorodną działalność prośrodowiskową. Rangę owego zaangażowania pokreślił List pasterski Episkopatu Polski na temat ochrony środowiska z dnia 2 maja 1989 roku. Szczególnie zobowiązani do działania czuli się franciszkanie, gdyż w 1979 roku papież Jan Paweł II ogłosił św. Franciszka z Asyżu patronem ekologów. Powstało zatem szereg ekologicznych inicjatyw, najczęściej związanych z duchowością franciszkańską. Grupy REFA i Franciszkańskiego Ruchu Ekologicznego działały między innymi w Krakowie, Katowicach, Wrocławiu, Legnicy, Poznaniu, Łodzi, Gdańsku, Warszawie, Lublinie i Jaśle. Katolickie ośrodki edukacji ekologicznej powstały między innymi w Krakowie, Lublinie, Zawoi w Beskidach i Wisełce na Pomorzu. Dziś istnieją nieliczne z nich. Trochę lepsza sytuacja jest, jak się wydaje, z naszymi inicjatywami turystycznymi i propagującymi wszechstronny wypoczynek wśród pięknej polskiej przyrody. Jednak ich walory poznawcze i edukacyjne zależą zawsze od świadomości organizatorów. Bardzo cenna jest tu metoda wypracowana przez Ruch Światło-Życie zachęcająca

13 Por. S. Jaromi, Co się dzieje z naszą piękną Ziemią? - Głos Kościoła Katolickiego w kwestii ochrony przyrody, w: M. Grzegorczyk i in. (red.), Mówić o ochronie przyrody. Zintegrowana wizja ochrony przyrody, Kraków 2002. 
do „wypraw otwartych oczu”, aby nawiązać osobisty, emocjonalny stosunek $\mathrm{z}$ otaczającym nas światem przyrody.

W ujęciu katolickiej nauki społecznej troska o przyrodę i ochronę środowiska jest też troską o stworzenie i łączy się z ochroną przestrzeni socjalnej, kulturowej, duchowej, ze środowiskiem wartości, gdzie sens, prawda, dobro, piękno będą wyznaczać środowisko i przestrzeń autentycznego rozwoju. Jest to wspólna troska o oikos, polis i oikumene, gdzie człowiek żyłby w harmonii z przyrodą, drugim człowiekiem, samym sobą i z Bogiem.

Wydaje się, że szczególnie ważny dla realizacji takiej wizji jest odpowiedni klimat intelektualny. Zanieczyszczenie środowiska intelektualnego przez ignorowanie prawdy i odpowiedzialności moralnej, przez zredukowanie ludzkiego życia do poziomu bohaterów seriali czy komiksów, przez slogany reklam i kicz popkultury, przez nihilizm i relatywizm, tworzy klimat, w którym trudno budować ambitną bioetykę, ekofilozofię czy teologię stworzenia.

Zatem choć obraz współczesnego świata ma charakter ambiwalentny, jest pełen świateł i cieni, to wydaje się jednak, że polski chrześcijanin próbujący tworzyć zintegrowany świat przyjazny dla wszystkich stworzeń, zgodny $\mathrm{z}$ wiarą katolicką, osiągnięciami nauk przyrodniczych i etyki jest w bardzo specyficznej sytuacji. Wprawdzie znajdzie teologię stworzenia rozwijaną przez ks. Romana Rogowskiego, o. Wacława Hryniewicza czy o. Zdzisława Kijasa oraz obecną u ks. Jana Twardowskiego, ks. Janusza Pasierba czy ks. Jerzego Szymika, którzy przez poezję i różne formy literackie pięknie przekształcają słowa w harmonię ogarniającą całą przestrzeń między Stwórcą i stworzeniem. Jednak szybko zorientuje się, że szereg podjętych tematów jest zaledwie zarysowanych, że ich apogeum przypadło kilkanaście lat temu, że nie są rozwijane przez kolejne pokolenia teologów. Zauważy też, że prawie brak duszpasterskich działań proekologicznych, tak licznie obecnych w innych krajach. Wprawdzie tematyka ekologiczna znalazła się w programie duszpasterskim Kościoła w Polsce na rok 2008/2009 Otoczmy troska życie wydanym przez Komisję Duszpasterstwa Konferencji Episkopatu Polski, który zachęcał do szerszego wprowadzenia w działania katechetyczne, kaznodziejskie, rekolekcyjne i każde inne duszpasterstwo szeroko rozumianej troski o życie. Przewodniczący komisji abp Stanisław Gądecki wyjaśniał: „Z pewnością nie chodzi tu o wąsko rozumianą obronę życia nienarodzonych ani o zagrożenia życia ludzkiego, chociaż nie można oczywiście tych problemów pominąć. Chodzi raczej o troskę o szeroko rozumiane wszystkie formy życia, które wyszły z rąk Stwórcy”'14. W tej szerokiej perspektywie

${ }^{14}$ Komisja Duszpasterstwa Konferencji Episkopatu Polski, „, Otoczmy troska życie”. Kościół niosacy Ewangelię Nadziei. Program duszpasterski Kościoła w Polsce na lata 2006-2010. Rok 2008/2009, Poznań 2008, s. 13. 
Arcybiskup widział troskę o życie fizyczne, psychiczne i duchowe człowieka oraz o życie środowiska naturalnego, a program wśród kilku projektów duszpasterskich prezentował Ruch Ekologiczny św. Franciszka z Asyżu (REFA) jako nowoczesny i ewangeliczny przykład troski o życie przyrody. Jednak wydaje się, że w głównym nurcie debaty teologicznej i duszpasterstwa są to sprawy nieobecne.

\section{Ekoinicjatywy w ramach Ogólnopolskiego Kongresu Ruchów i Stowarzyszeń Katolickich}

Jednak poza tym głównym nurtem podejmowane są różne inicjatywy i projekty. Uwagę zwracają szczególnie te, które inicjowane są przez Ogólnopolską Radę Ruchów Katolickich, szczególnie w czasie kolejnych kongresów organizowanych dla liderów ruchów. Wyjątkowo mocno zagadnienie ekologii w posłudze apostolskiej podjęto w ramach III Ogólnopolskiego Kongresu Ruchów i Stowarzyszeń Katolickich, który odbywał się w latach 2005-2007. Został on zaplanowany jako pogłębiona, systematyczna i nowoczesna refleksja nad nowymi wyzwaniami na początku nowego tysiąclecia. Podstawową metodą pracy były odbywające się co miesiąc kolejne kongresy tematyczne, poświęcone między innymi rodzinie, ekologii, kulturze, mistyce, globalizacji, młodzieży czy mediom. W sumie można było wysłuchać ponad 350 referatów, wykładów i świadectw oraz dyskusji panelowych, w których uczestniczyło ponad trzy tysiące osób. Inni swoimi doświadczeniami zaangażowania w Kościele mogli dzielić się za pośrednictwem kongresowego serwisu internetowego ${ }^{15}$.

$\mathrm{W}$ jednym z kongresów tematycznych próbowano zrozumieć sprawy ekologii z perspektywy chrześcijańskiej oraz drogi, poprzez które możemy bardziej troszczyć się o stworzenie w Duchu Świętym. Za przygotowanie i koordynację obszaru zagadnień na temat chrześcijańskiego zaangażowania w ekologię był odpowiedzialny Ruch Ekologiczny św. Franciszka z Asyżu REFA. Członkowie REFA przygotowali specjalną stronę internetową z materiałami poświęconymi chrześcijańskiej ekologii oraz 19 listopada 2005 w Warszawie zorganizowali specjalną sesję na temat Chrześcijanin a ekologia. Został też wydany folder zapoznający z tematyką i zakresem działalności REFA oraz specjalna 104-stronicowa publikacja pod tytułem Chrześcijanin

${ }^{15}$ Bogata dokumentacja zob.: Serwis ORRK www.orrk.pl 
a ekologia ${ }^{16}$. Obszerny materiał podsumowujący wszystkie działania został opublikowany na stronie kongresowej oraz w specjalnej książce ${ }^{17}$.

W dniach 16 i 17 czerwca 2007 w Warszawie odbyła się sesja podsumowująca owoce podjętych w tym czasie działań. Uczestniczyło w niej ponad siedemset osób z Polski i zagranicy. Gościem specjalnym sesji był abp Stanisław Ryłko z Watykanu, przewodniczący Papieskiej Rady ds. Świeckich. Podkreślono wtedy, że sam fakt wyróżnienia w oddzielny blok tematyczny i zorganizowanie Kongresu Chrześcijanin a ekologia w ramach Ogólnopolskiego Kongresu Ruchów i Stowarzyszeń Katolickich świadczy o tym, że problem ochrony środowiska został dostrzeżony jako istotny w życiu chrześcijanina, Kościoła i społeczeństwa. Jednocześnie okazało się, że wiedza na temat kwestii ekologicznej i zainteresowanie nią nie jest zbyt wielkie. Nie ulega jednak wątpliwości fakt, że zorganizowany przez REFA kongres tematyczny uświadomił, jak szeroka jest to problematyka i jakie znaczenie powinna mieć w życiu chrześcijanina (czyli większości polskiego społeczeństwa); rozbudził wrażliwość ekologiczną i zwrócił uwagę, że ochrona środowiska jest $\mathrm{w}$ istocie kwestią ochrony życia i odpowiedzialności za nie.

Według REFA, z dyskusji kongresowych wyłoniło się kilka ważnych propozycji:

1. Poprawa skuteczności nauczania chrześcijańskich wartości w kwestii ekologicznej poprzez przygotowanie odpowiednich materiałów dla duszpasterzy, katechetów, nauczycieli i wszystkich zainteresowanych.

2. Stworzenie centralnego ośrodka chrześcijańskiej edukacji ekologicznej.

3. Włączanie w liturgię modlitw w intencjach szacunku dla Dzieła Bożego, zwłaszcza dla wody, ziemi i dóbr przyrody.

4. Organizowanie okolicznościowych dni ekologicznych, włączonych w program parafii, wspólnot, wakacyjnych lub szkolnych wyjazdów, których celem, poza ciekawym wykorzystaniem czasu i miejsca czy zdobywaniem nowej wiedzy, byłoby ukształtowanie postawy szacunku do świata przyrody jako Bożego stworzenia oraz wzbudzenie poczucia odpowiedzialności za przyrodę.

5. Propagowanie osoby i duchowości Patrona Ekologów, świętego Franciszka z Asyżu, jako „znaku orientacyjnego” wśród różnych propozycji edukacji ekologicznej.

${ }^{16}$ Chrześcijanin a ekologia, Zielony Zeszyt REFA 2005, numer specjalny, Warszawa 2005.

${ }^{17}$ S. Jaromi, Chrześcijanin a ekologia, w: A. Schulz (red.), Stużyć Królestwu Bożemu w świecie. III Kongres Ogólnopolski Ruchów i Stowarzyszeń Katolickich, Warszawa 2007, s. $107-121$. 
6. Zachęta dla katolików, aby podejmowali refleksję nad stylem swego życia, zwłaszcza mając na uwadze sprawy jakości życia, zdrowie, spędzanie wolnego czasu, potrzeby, postawy konsumpcyjne, produkcję nadmiernych ilości odpadów itp.

7. Podkreślenie działań wychowawczych z dziećmi, aby ukształtować W nich wrażliwość na piękno, urodę świata i mądrość natury ${ }^{18}$.

Podobnie służbę ekologii podjęto w ramach IV Ogólnopolskiego Kongresu Ruchów i Stowarzyszeń Katolickich, odbywającego się w latach 2010-2011. Tym razem próbowano szukać odpowiedzi na pytania: jak rozwijać postawy proekologiczne oraz chrześcijańskie podejście do konsumpcji?; jak na nowe wyzwania powinni odpowiedzieć chrześcijanie?; czy obecne katastrofy ekologiczne powinniśmy odczytać jako „znaki czasu”?

Próbę odpowiedzi podjęto w czasie konferencji Chrześcijanin wobec współczesnych wyzwań ekologii i konsumpcji, zorganizowanej $\mathrm{w}$ dniu 22 maja 2010 roku w Warszawie. Okazało się, że świat konsumpcyjny zakłada na nas liczne pułapki, bo „konsumpcja to nie tylko nabywanie rzeczy, ale ich zawłaszczenie i zużycie, tak że inni zostają ich pozbawieni. Mentalność konsumpcyjna wywiera wpływ na sposób życia i styl zachowań osób i społeczności. Człowiek wyznając kult posiadania oddala się od wartości kulturowych a nawet moralnych czy religijnych i ostatecznie opowiada się za materializmem"19.

Zaprezentowano różne tematy ekologiczne z perspektywy chrześcijańskiej, między innymi problematykę bioróżnorodności i zmian klimatu, GMO w rolnictwie i odpowiedzialności za katastrofy ekologiczne.

To wszystko każe nam z większą troską dbać o nasz świat i uznać jego bioróżnorodność za dar Stwórcy i wartość samą w sobie. Fiasko negocjacji klimatycznych i inwazja GMO w rolnictwie świadczą jednak o zwycięstwie działań wyłącznie dla zysku i egoizmie najbogatszych. Głos chrześcijan musi zatem wołać o większą odpowiedzialność za kształt naszej cywilizacji, troskę o stworzenie i potrzeby najuboższych ${ }^{20}$.

Pokazano też przykłady chrześcijańskiej edukacji ekologicznej w Polsce, jak projekt Młodzi tej ziemi, prowadzony przez Katolickie Stowarzyszenie Młodzieży, które edukuje poprzez terenowe warsztaty edukacji ekologicznej, warsztaty dla chrześcijańskich edukatorów ekologicznych i portal

\footnotetext{
18 Tamże, s. 118n.

${ }_{19}$ K. Kietliński, Chrześcijanin jako konsument, mps.

${ }^{20}$ Por. relacja z konferencji w: http://www.refa.franciszkanie.pl/index.php?function= show_all\&no=215
} 
społecznościowy. Inne inicjatywy to projekty Ogrodów św. Franciszka i tak zwana Mapa chrześcijańskich inicjatyw ekologicznych. Celem owej mapy jest zebranie informacji na temat inicjatyw ekologicznych, podejmowanych przez parafie, klasztory, ruchy i stowarzyszenia kościelne bądź przez indywidualnych chrześcijan a następnie ich rozpropagowanie oraz przekazywanie informacji osobom poszukującym przykładów chrześcijańskiego zaangażowania w ochronę środowiska.

Natomiast Ogrody św. Franciszka nawiązują do idei wyrażonej przez Patrona Ekologów, aby przy klasztorach pozostawiać „nieuprawne obrzeże, aby na nim w swoich porach zieleń ziół i piękno kwiatów głosiły Ojca wszystkich pięknych rzeczy"'21. Takie naturalne, półnaturalne lub komponowane ogrody mają oprócz aspektów przyrodniczo-dydaktycznych realizować cele społeczne lokalnej wspólnoty i być miejscem do odpoczynku, kontemplacji i spędzania wolnego czasu w otoczeniu przyrody ${ }^{22}$.

Przedstawione skrótowo prace kongresowe i towarzyszące im dyskusje zaowocowały sformułowaniem najważniejszych wniosków i wskazówek, wyznaczających kierunki i obszary zaangażowania Kościoła w kwestii ekologicznej. Na podstawie tego ogromnego materiału można sformułować następujące inspiracje i wskazania:

a) styl życia jako świadectwo chrześcijan na dzisiejszy czas - styl podkreślający wartość i bogactwo całego życia, umiar i odpowiedzialność za dzieło Boże, a nie goniący za konsumpcją, zaspokajaniem potrzeb materialnych i tym samym większą eksploatacją dóbr przyrody;

b) pogłębienie znajomości nauczania społecznego Kościoła w kwestii ekologicznej;

c) propagowanie pełnej wizji zagadnień ekologicznych, obejmującej zarówno autentyczne potrzeby ludzkie, jak i troskę o cały stworzony świat;

d) poszerzanie świadomości ekologicznej społeczeństwa i traktowanie ochrony środowiska przyrodniczego nie jako uciążliwości w zaspokajaniu własnych potrzeb, lecz jako szczególnego obowiązku każdego chrześcijanina;

${ }^{21}$ Tomasz z Celano, Życiorys drugi Świętego Franciszka z Asyżu, Rozdz. CXXIV, p. 165, w: Wczesne źródła franciszkańskie, t. 1, s. 167. Podstawowym źródłem wiedzy o św. Franciszku z Asyżu (1182-1226) i jego relacji do świata przyrody są jego pisma oraz tzw. wczesne źródła franciszkańskie, obejmujące teksty powstałe w środowisku franciszkańskim bezpośrednio po śmierci założyciela.

${ }^{22}$ Szersze omówienie w: S. Jaromi, Idea ogrodu św. Franciszka jako przykład chrześcijańskiej troski o bioróżnorodność, w: J. Brusiło (red.), Ogród Pana. XVIII Seminarium Sacrum i przyroda, Kraków 2010, s. 83-94. 
e) troska o tzw. małą ekologię domową - o czystość powietrza, wody, ziemi; o ciszę i dobrą atmosferę sąsiedzką; o oszczędność żywności, wody, energii i wszystkich zasobów naturalnych;

f) rozwijanie wrażliwości na piękno stworzenia jako drogi afirmacji Stwórcy - modlitwa poprzez kontemplację przyrody;

g) włączenie się we Franciszkański Projekt Edukacji Ekologicznej realizowany przez Ruch Ekologiczny św. Franciszka z Asyżu ${ }^{23}$.

\section{REFA jako nowoczesny i ewangeliczny przykład troski o życie przyrody}

Ruch Ekologiczny św. Franciszka z Asyżu - REFA powstał w 1981 roku w Krakowie jako bezpośrednia reakcja Franciszkanów na ogłoszenie 29 listopada 1979 roku św. Franciszka z Asyżu patronem ekologów przez papieża Jana Pawła II. Innym motywem był ówczesny kontekst społeczno-polityczny Polski, który sprawił ujawnienie rzeczywistego zagrożenia ekologicznego naszego kraju. Chęć ekologicznego działania jawiła się zatem jako konkretna droga realizacji franciszkanizmu we współczesnej sytuacji.

Jako część bardzo zróżnicowanego i wieloaspektowego społecznego ruchu ekologicznego w Polsce według socjologicznego kryterium stylu działania możemy być zaliczeni do grup, które powstały w celu prowadzenia działalności długofalowej, obejmującej wiele problemów ekologicznych i zmierzającej do zasadniczych zmian społecznych. Zawsze akcentowaliśmy tak zwaną „małą drogę" prowadzącą od kształtowania indywidualnych postaw proekologicznych do konkretnych działań. Miało to wyrazić hasło „Ekologia zaczyna się od serca" i znaczek Ruchu, w którego centralnym miejscu znajduje się serce niesione przez duchowego syna św. Franciszka, który poprzez symboliczny zielony liść jest trwale zjednoczony ze światem stworzeń.

Jak już nadmieniono, REFA wspomniano w programie duszpasterskim Kościoła w Polsce na rok 2008/2009 wydanym przez Komisję Duszpasterstwa Konferencji Episkopatu Polski, który zachęcał do szerszego wprowadzenia w działania katechetyczne, kaznodziejskie, rekolekcyjne i każde inne duszpasterstwo szeroko rozumianej troski o życie i prezentował Ruch Ekologiczny św. Franciszka z Asyżu (REFA) jako nowoczesny i ewangeliczny przykład troski o życie przyrody.

REFA łączy duchowe bogactwo ekologii franciszkańskiej (od czasów Świętego, przez tradycje przyrodnicze franciszkanów, do aktualnej ekologicznej myśli

${ }^{23}$ Szczegółowo jest on prezentowany na stronach internetowych www.refa.franciszkanie.pl 
franciszkańskiej), ze współczesną chrześcijańską nauką o środowisku przyrodniczym, podkreślając zwłaszcza nauczanie Kościoła katolickiego o środowisku naturalnym, ekologii i ochronie przyrody. Wszystko razem opiera się na chrześcijańskiej koncepcji świata i człowieka stworzonego przez Boga, odkupionego przez Chrystusa i uświęconego przez Ducha Świętego ${ }^{24}$.

Prezentując genezę franciszkańskiego zaangażowania w ekologię, Autor tekstu wyjaśnia:

Ruch Ekologiczny św. Franciszka z Asyżu powstał jako odpowiedź na współczesne zagrożenia ekologiczne, dlatego też zamierzenia stowarzyszenia wychodzą naprzeciw znakom czasu i potrzeby ochrony przyrody zarówno w skali regionów, jak i całego kraju czy kontynentu, razem z innymi grupami i stowarzyszeniami proekologicznymi, które mają podobne założenia w swojej działalności. W tym kontekście Ruch stara się działać nie tylko na przykład w kierunku proekologicznych zmian ustawodawczych w całym społeczeństwie, ale również w kierunku kształtowania myślenia i sumienia w każdym człowieku. Akcje REFA - z założenia - wpisują się w globalny program ochrony przyrody i są skierowane do biblijnego centrum osoby ludzkiej - do serca, w którym doświadcza się zarówno skutków globalnych zagrożeń ekologicznych, jak i kształtuje się konkretna odpowiedź człowieka na te zagrożenia w najbliższym otoczeniu $^{25}$.

Po omówieniu licznych konkretnych działań REFA i jego kręgów następuje podsumowanie:

Niewątpliwie idee REFA nie są obszarem zamkniętym na nowe inspiracje i działania o charakterze religijnym, społecznym i ekologicznym. Dotychczasowe, długofalowe projekty i akcje w ponad 25-letniej działalności REFA pokazały właściwy kierunek chrześcijańskiej troski o przyrodę. Działalność Ruchu ma nie tylko przyszłość, ale jest bardzo potrzebna z punktu widzenia społeczno-ekologicznego zaangażowania Kościoła i z punktu widzenia duchowego umocnienia ekologicznych celów i dążeń przyrodników skupionych w proekologicznych stowarzyszeniach i organizacjach świeckich. Wspólnym mianownikiem tych idei jest franciszkańskie otwarcie na przyrodę i duchowy dialog z całym stworzeniem, które św. Franciszek nazwał braćmi i siostrami. Nie tylko chrześcijańska i franciszkańska teologia stworzenia, ale i etyka,

${ }^{24}$ J. Brusiło, Ruch Ekologiczny św. Franciszka z Asyżu (REFA) jako nowoczesny i ewangeliczny przykład troski o życie przyrody, w: ,, Otoczmy troska życie”, s. 342.

${ }^{25}$ Tamże, s. 343. 
ochrona i troska o środowisko naturalne jest w centrum zainteresowania człowieka, a narzędziem do poznawania świata przyrody oraz do ratowania zagrożonego środowiska może być ciągle aktualna myśl Świętego z Asyżuª ${ }^{26}$.

Warto dodać, że idee REFA są kształtowane przez:

1. Franciszkową wizję solidarności i braterstwa ze wszystkimi stworzeniami, którą dobrze wyraża współcześnie sformułowany dekalog św. Franciszka, oparty na jego pismach i wczesnych źródłach franciszkańskich.

2. Fascynację pięknem przyrody, ale też przez „wstrząs ekologiczny” spowodowany poznawaniem ogromu kryzysu ekologicznego w Polsce i świecie, osobiste zetknięcie ze skutkami niszczenia przyrody i zdrowia człowieka oraz gruntowną wiedzę przyrodniczą, ekologiczną, filozoficzną i teologiczną.

3. Społeczne nauczanie Kościoła i myśl Jana Pawła II, gdyż cel Ruchu rozumiemy jako „czynny udział w budowaniu cywilizacji miłości opartej na prymacie osoby przed rzeczą, etyki przed techniką, umiłowania tego, aby «bardziej być» przed dążeniem, aby «więcej mieć», miłosierdzia przed sprawiedliwością, poprzez braterskie traktowanie człowieka i przyrody"27.

Wśród długofalowych projektów REFA warto wymienić:

- Franciszkański Projekt Edukacji Ekologicznej, w ramach którego przygotowaliśmy szereg materiałów edukacyjnych, liturgicznych i kaznodziejskich, popularyzujących chrześcijańskie podejście do ekologii, społeczne nauczanie Kościoła i duchowość franciszkańską.

- Warsztaty Ekologiczne REFA, na które zapraszamy każdego roku do wybranego parku narodowego lub parku krajobrazowego;

- Mapę Chrześcijańskich Inicjatyw Ekologicznych, gdzie gromadzimy dane o inicjatywach ekologicznych podejmowanych z inspiracji chrześcijańskich na terenie Polski;

- Ogrody Brata Franciszka, promujące zachowanie naturalnych lub półnaturalnych ekosystemów poprzez społeczną ochronę ostoi przyrody;

- Projekt Brehov - międzynarodowe spotkania młodych z franciszkańskich duszpasterstw krajów Europy Wschodniej, w które włączamy się z edukacją ekologiczną;

26 Tamże, s. 345.

${ }^{27}$ Por. Statut Ruchu Ekologicznego św. Franciszka z Asyżu, w: http://www.refa.franciszkanie.pl/index.php?id=onas/statut 
- Zielony Zeszyt REFA - nasz biuletyn ukazujący się od 1988 roku, prezentujący odpowiedzi na wiele pytań dotyczących chrześcijańskiej ekologii, refleksję nad miejscem naszego Świętego Patrona w aktywności społecznej oraz praktyczne propozycje do wykorzystania w edukacji ekologicznejes.

Kończąc tę krótką prezentację zaangażowania katolickich ruchów i stowarzyszeń w działalność ekologiczną, chciałbym przywołać metaforę, jaką użył o. Joseph Vandris wieloletni, nieżyjący już, rzymski korespondent „LeFigaro", który zafascynowany Janem Pawłem II napisał o nim książkę Ce jour-l? Jean-Paul II, zbudowaną na 50 kluczowych wydarzeniach pontyfikatu, których był świadkiem. Strategię Jana Pawła określił tak: Papież zajmował się oczyszczaniem źródeł, a nie naprawianiem kanalizacji. Oczyszczanie źródeł, abyśmy dostali wodę czystą i zdrową - to dobra metafora na określenie istoty wielkiego fenomenu naszych czasów, jakim jest chrześcijańska troska o stworzenie i środowisko ludzkiego życia. To też podstawowe zadanie dla katolików w służbie ekologii.

\section{Movements and Associations in the Church in the Service of Ecology (Summary)}

The paper aims at presenting theoretical foundations of the Catholics' engagement in the proecological activities as well as chosen examples of such activities undertaken in the Polish Catholic Church. Building up an integral, christian vision of creation we cannot miss on the context of modernity using our present knowledge of nature, ecological crisis or the reflection on social, cultural, economic phenomena. Many an inspiration in this work are given by the Bible, church tradition, theology, and social teachings of the Church. The contemporary Christian Gospel of life is a basis of Christian care of the creation and human environment. A good example of such engagement is the activity of the Ecological Movement of St Francisco of Assisi (Ruch Ekologiczny św. Franciszka z Asyżu - REFA) showed as a modern and evangelical example of the care of nature and the project of the Polish Council of Catholic Movements (Ogólnopolska Rada Ruchów Katolickich) forming leaders of Catholic movements and associations in Poland.

${ }^{28}$ Por. Zielony Zeszyt REFA, kolejne wydania w latach 1999-2009. Szersze omówienie działań Ruchu oraz zadań chrześcijańskiej ekologii we współczesnym świecie w: S. Jaromi, Eko-book o Eko-Bogu, Kraków 2010. 